\title{
A Localized Painful Rash Induced by Linagliptin in a Patient with type 2 Diabetes
}

\author{
Tip 2 Diyabetli Bir Hastada Linagliptine Bağlı Lokalize Ağrılı Döküntü
} \begin{abstract}
(1) Yasemin Yuyucu Karabulut3
${ }^{3}$ Mersin University Faculty of Medicine, Department of Patology, Mersin, Turkey

\section{ABSTRACT}

The number of patients with type 2 diabetes using dipeptidyl peptidase-4 (DPP-4) inhibitors is increasing across the world.

Although this class of antidiabetic medications is generally safe and associated with less side effects compared to other oral antidiabetic medications, they could also cause some side effects such as skin rashes. Herein we report a case of type 2 diabetes patient who developed a painful maculopapular rash induced by linagliptin, a widely used DPP-4 inhibitor.

A localized painful maculopapular rash developed on the palmar faces of the patient's hands almost 1 day after the initiation of the drug. The patient was using intensive insulin therapy before linagliptin was started. There was no eruption on the other body parts except the palmar faces of the hands. Following the discontinuation of the drug, the rash disappeared in about four days. The patient had no history of urticaria and did not use an ACE inhibitor. As far as we know, this is the first case report of a skin rash induced by linagliptin in the Turkish literature. This case report highlights a rare and lesser known side effect of linagliptin, a new member of DPP-4 inhibitors.

Keywords: Linagliptin, DPP-4 inhibitor, rash skin eruption, type 2 diabetes mellitus

\section{Introduction}

A localized painful maculopapular rash developed on the palmar faces of both hands of a patient almost one day after the initiation of linagliptin, a new member of dipeptidyl peptidase inhibitors-4 (DPP-4). The patient was using intensive insulin therapy before linagliptin was started. There was no eruption on the other body parts except the palmar faces of the hands. When the drug was discontinued, the rash immediately disappeared in about four days. The patient had no urticaria and did not use an angiotensin converting enzyme (ACE) inhibitor.
\end{abstract}

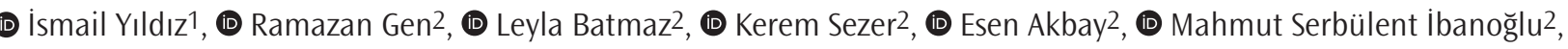

${ }^{1}$ Tekirdağ Namık Kemal University Faculty of Medicine, Department of Endocrinology and Metabolism, Tekirdağ, Turkey 2Mersin University Faculty of Medicine, Department of Endocrinology and Metabolism, Mersin, Turkey

\section{öz}

Dipeptidil peptidaz-4 (DPP-4) inhibitörleri kullanan tip 2 diyabet hastalarının sayısı dünya genelinde artmaktadır.

Bu antidiyabetik ilaç sınıfı genelde güvenli olmakla birlikte diğer oral antidiyabetik ilaçlarla karșılaștırıldığında daha az yan etki ile ilişkili olsa da, deri döküntüleri gibi bazı yan etkilerle ilişsili olabilirler. Burada yaygın olarak kullanılan bir DPP-4 inhibitörü olan linagliptin ile indüklenen ağrılı makülopapüler döküntü gelişen tip 2 diyabetli bir hastayı sunuyoruz.

Linagliptin başlandıktan 1 gün sonra hastamızın ellerinin palmar yüzünde lokalize ağrılı makülopapüler bir döküntü geliști. Linagliptin bașlanmadan önce hasta intensif insülin tedavisi altındaydı. Vücudun diğer bölgelerinde herhangi bir döküntü yoktu. Linagliptin kesildikten sonra 4 gün içerisinde döküntü kayboldu. Hastanın ürtiker öyküsü yoktu ve Anjiyotensin dönüștürücü enzim inhibitörü kullanmıyordu. Bildiğimiz kadarıyla bu, Türk literatüründe Linagliptine bağ|ı deri döküntüsü geliștirdiği rapor edilen ilk olgudur. Bu olgu sunumu, DPP-4 inhibitörlerinin nadir görülen ve daha az bilinen bir yan etkisini vurgulamaktadır.

Anahtar Kelimeler: Linagliptin, DPP-4 inhibitörleri, makülopapüler cilt döküntüsü, tip 2 diabetes mellitus
Contrary to other DPP-4 inhibitors, linagliptin is generally used for diabetic patients who have different stages of renal failure. This case shows that linagliptin can also induce skin reactions like other DPP-4 inhibitors.

\section{Case Report}

A-54-year old female patient with newly diagnosed type 2 diabetes was admitted to our outpatient clinic due to nausea, vomiting, polyuria, and polydipsia. She had a history of essential hypertension. She had not any 
fever, skin rash or other signs of infectious diseases. Except for reduced skin turgor and tonus, the physical examination was normal.

On biochemical analysis, her fasting plasma glucose, hemoglobin A1c (HbA1c), white blood cell (WBC) count, serum creatinine, blood urea nitrogen (BUN), and C-reactive protein levels were $300 \mathrm{mg} / \mathrm{dL}, 9.8 \%$, 17.000 (70\% neutrophil), $1.7 \mathrm{mg} / \mathrm{dL}, 60 \mathrm{mg} / \mathrm{dL}$, and $3 \mathrm{mg} / \mathrm{L}(<5 \mathrm{mg} / \mathrm{L})$, respectively. She did not have ketonuria or acidosis and the serum potassium level was normal.

One day after starting rehydration with isotonic saline infusion for acute renal injury and intensive insulin therapy for hyperglycemia, the skin turgor and tonus, fasting and postprandial plasma glucose, serum creatinine, BUN, and WBCs count returned to normal values.

On the $3^{\text {rd }}$ day after admission, metformin was added to the insulin treatment, but dyspeptic complaints and watery diarrhea developed. For this reason, metformin was stopped and linagliptin, a DPP-4 inhibitor, was added.

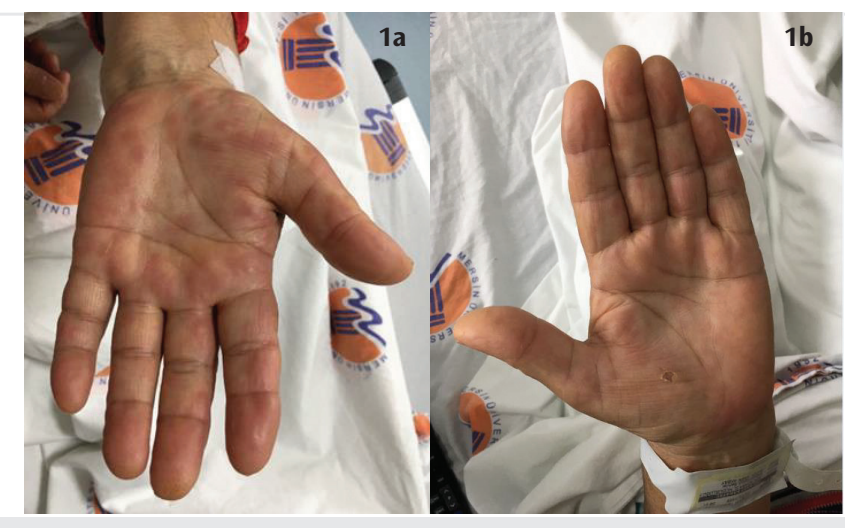

Figure 1. a) Hyperemic maculopapular rash on the palmar faces of the hands, b) disappearance of the rash after the cessation of the linagliptin

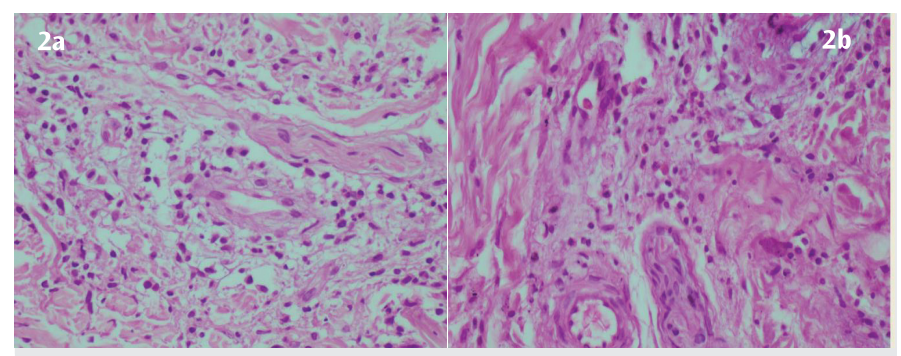

Figure 2. a, b) Eosinophils

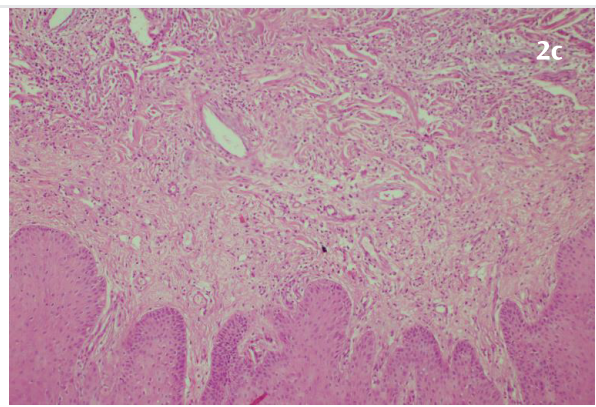

Figure 2. c) A histopathologic view (haematoxylin and eosin staining) of an eosinophilic superficial dermatitis taken from the skin biopsy of the patient
However, one day later, the patient developed a painful, hyperemic, maculopapular rash (Figure 1) without itching on the palmar faces of the both hands. The rash was thought to be related to linagliptin and treatment was therefore stopped.

The patient's informed consent form was taken. A skin biopsy performed by a dermatologist revealed an eosinophilic superficial dermatitis (Figure 2). So, a diagnosis of an allergic skin reaction against linagliptin was made and treatment with betamethasone ointment was started. Four days after the treatment of linagliptin, this treatment was stopped, treatment with betamethasone ointment was started, and pain and maculopapular rash disappeared completely.

\section{Discussion}

DPP-4 inhibitors are orally active drugs used for the treatment of type 2 diabetes (1). DPP-4 is a cell-surface protease that inactivates the incretin hormones, the glucagon-like peptide-1 (GLP-1) and the glucose-dependent insulinotropic polypeptide (GIP). The incretins play an important role in glucose homeostasis, stimulating insulin secretion, suppressing glucagon release, and slowing gastric emptying.

The DPP-4 inhibitors increase the circulating concentrations of incretin hormones (GIP, GLP-1) and also decrease plasma glucose concentrations in type 2 diabetes patients (2-5). In clinical trials on type 2 diabetic patients, the addition of a DPP-4 inhibitor decreases fasting glucose and HbA1c and improves insulin secretion $(6,7)$.

There have been post-marketing reports of serious hypersensitivity reactions in patients treated with sitagliptin. These reactions include anaphylaxis, angioedema, and exfoliative skin reactions including Stevens-Johnson syndrome. The onset of these reactions generally occurs within the first 3 months of the initiation of the treatment with sitagliptin, and even some reactions occur after the first dose of the drug (8). Nakatani et al. (9) have reported a drug-induced generalized skin eruption in a diabetes mellitus patient receiving sitagliptin plus metformin. Attaway et al. (10) also have reported a case of bullous pemphigoid associated with sitagliptin.

There are a few reports about the anaphylactic reactions and skin lesions occurring after the use of sitagliptin or vildagliptin. Although a few reports are available in English literature demonstrating skin reactions induced by linagliptin, Esposito et al. (11) have recently reported a case of bullous pemphigoid induced by linagliptin. Also, Psomadakis et al. (12) have reported a case of linagliptin-associated blistering and ulceration. In the present case, linagliptin was used in addition to intensive insulin therapy. After the initiation of linagliptin, the patient developed maculopapular lesions on the palmar aspects of the hands, which resolved in four days after stopping the drug.

In our patient, although metformin was used for a short period of time (2 days), the skin eruption occurred just after adding linagliptin to the treatment. The occurrence of skin eruption after starting linagliptin and the disappearance of the eruption after the discontinuation of linagliptin suggests that linagliptin might be the cause of skin eruption in our patient.

Despite the long term history of metformin use, drug-induced rash after metformin therapy has rarely been reported, and the most commonly 
reported skin reactions due to metformin are psoriasis form eruption (13) and leukocytoclastic vasculitis (14). Therefore, the skin reaction in our patient is thought to be due to linagliptin.

\section{Conclusion}

The present case suggests that linagliptin may also cause skin reactions similar to other DPP-4 inhibitors, such as sitagliptin and vildagliptin, which can lead to skin reactions such as bullous pemphigoid in particular.

Therefore, patients taking this class of drugs with or without a history of urticaria should be considered and treatment should be discontinued after skin reactions occur. However, it is not well known whether cross reaction would develop after switching to another DPP-4 inhibitor in patients with skin rash occurring after starting a DPP-4 inhibitor. However, close follow-up of patients who have skin reactions after the use of DPP-4 inhibitor or who have been switched to another DPP-4 inhibitor is necessary to prevent serious skin reactions. This case also suggests that local glucocorticoid ointments are generally effective in the treatment of localized skin reactions induced by DPP-4 inhibitors.

Informed Consent: The patient's informed consent form was taken.

Peer-review: External and internal peer-reviewed.

Author Contributions: Concept - I.Y., R.G., L.B., M.S.I.; Design - I.Y., K.S., E.A.; Supervision - I.Y., R.G., E.A.; Resources - I.Y., L.B. M.S.I.; Analysis and/ or Interpretation - I.Y., R.G., L.B., ; Literature Search - I.Y., K.S., M.S.I., Y.Y.K.; Writing Manuscript - I.Y., R.G., L.B.; Critical Review - R.G., K.S., E.A.

Conflict of Interest: No conflict of interest was declared by the authors.

Financial Disclosure: The authors declared that this study received no financial support.

\section{References}

1. Drucker DJ, Nauck MA. The incretin system: glucagon-like peptide-1 receptor agonists and dipeptidyl peptidase-4 inhibitors in type 2 diabetes. Lancet 2006; 368: 1696-705

2. Mari A, Sallas WM, He YL, Watson C, Ligueros-Saylan M, Dunning BE, et al. Vildagliptin, a dipeptidyl peptidase-IV inhibitor, improves model-assessed beta-cell function in patients with type 2 diabetes. J Clin Endocrinol Metab 2005; 90: 4888-94

3. Pratley RE, Jauffret-Kamel S, Galbreath E, Holmes D. Twelve-week monotherapy with the DPP-4 inhibitor vildagliptin improves glycemic control in subjects with type 2 diabetes. Horm Metab Res 2006; 38: 423-8.

4. Raz I, Hanefeld M, Xu L, Caria C, Williams-Herman D, Khatami H, et al. Efficacy and safety of the dipeptidyl peptidase- 4 inhibitor sitagliptin as monotherapy in patients with type 2 diabetes mellitus. Diabetologia 2006; 49: 2564-71.

5. Herman GA, Bergman A, Stevens C, Kotey P, Yi B, Zhao P, et al. Effect of single oral doses of sitagliptin, a dipeptidyl peptidase-4 inhibitor, on incretin and plasma glucose levels after an oral glucose tolerance test in patients with type 2 diabetes. J Clin Endocrinol Metab 2006; 91: 4612-9.

6. Ahren B, Pacini G, Foley JE, Schweizer A. Improved meal-related beta-cell function and insulin sensitivity by the dipeptidyl peptidase-IV inhibitor vildagliptin in metformin-treated patients with type 2 diabetes over 1 year. Diabetes Care 2005; 28: 1936-40.

7. Hermansen K, Kipnes M, Luo E, Fanurik D, Khatami H, Stein P, et al. Efficacy and safety of the dipeptidyl peptidase-4 inhibitor, sitagliptin, in patients with type 2 diabetes mellitus inadequately controlled on glimepiride alone or on glimepiride and metformin. Diabetes Obes Metab 2007; 9: 733-45.

8. JANUVIA ${ }^{\text {TM }}$ (sitagliptin) Prescribing Information. MERCK and CO, Inc. Whitehouse Station, NJ; 2007.

9. Nakatani K, Kurose T, Hyo T, Watanabe K, Yabe D, Kawamoto T, Seino Y. Druginduced generalized skin eruption in a diabetes mellitus patient receiving a dipeptidyl peptidase-4 inhibitor plus metformin. Diabetes Ther 2012; 3: 14.

10. Attaway A, Mersfelder TL, Vaishnav S, Baker JK. Bullous pemphigoid associated with dipeptidyl peptidase IV inhibitors. A case report and review of literature. J Dermatol Case Rep 2014; 8: 24-8.

11. Esposito I, Moretta G, Peris K, De Simone C. Linagliptin-induced bullous pemphigoid. Int J Dermatol 2017; 56: 1467-9.

12. Psomadakis C, Shahzad N, Katz J. Linagliptin-associated blistering and ulceration. BMJ Case Rep 2017: 2017.

13. Koca R, Altinyazar HC, Yenidünya S, Tekin NS. Psoriasiform drug eruption associated with metformin hydrochloride: a case report. Dermatol Online J 2003; 9: 11

14. Ben Salem C, Hmouda H, Slim R, Denguezli M, Belajouza C, Bouraoui K. Rare case of metformin-induced leukocytoclastic vasculitis. Ann Pharmacother 2006; 40: 1685-7. 